\title{
Effects of GHX02 on Chronic Obstructive Pulmonary Disease Mouse Model
}

\author{
Won-Kyung Yang ${ }^{1,2 \dagger}$, Yee Ran $\mathrm{Lyu}^{2 \dagger}$, Seung-Hyung Kim ${ }^{1}$, Yang Chun Park ${ }^{1,2^{*}}$ \\ ${ }^{1}$ Institute of Traditional Medicine and Bioscience, Daejeon University, Daejeon, Korea. \\ ${ }^{2}$ Division of Respiratory System, Dep. of Internal Medicine, College of Korean Medicine, Daejeon University, Daejeon, \\ Korea.
}

Objectives: Chronic obstructive pulmonary disease (COPD) is characterized by chronic inflammation and irreversible airflow. This study aimed to evaluate the effects of GHX02 in a COPD-induced mouse model.

Methods: The COPD mouse model was established by exposure to cigarette smoke extract and lipopolysaccharide which were administered by intratracheal injection three times with a 7 day interval. GHX02 $(100,200,400 \mathrm{mg} / \mathrm{kg})$ and all other drugs were orally administrated for 14 days from Day 7 to Day 21 .

Results: GHX02 significantly decreased the neutrophil counts in bronchoalveolar lavage fluid (BALF) and the number of $\mathrm{CD}^{+}, \mathrm{CD} 8^{+}, \mathrm{CD} 69^{+}$, and $\mathrm{CD} 11 \mathrm{~b}^{+} / \mathrm{GR} 1^{+}$cells in BALF and lung cells. GHX02 also suppressed the secretion of tumor necrosis factor-alpha (TNF- $\alpha$ ), interleukin-17A, macrophage inflammatory protein 2 (MIP2), and chemokine ( $\mathrm{C}-\mathrm{X}-\mathrm{C}$ motif) ligand 1 (CXCL-1) in BALF and ameliorated the lung pathological changes. Conclusions: Thus, GHX02 effectively inhibited airway inflammation by inhibiting migration of inflammatory cells and expression of pro-inflammatory cytokines. Therefore, GHX02 may be a promising therapeutic agent for COPD.

Key Words : chronic obstructive pulmonary disease, cigarette smoke, aimay inflammation, herbal medicine, GHX02

\section{Introduction}

Chronic obstructive pulmonary disease (COPD) is a major cause of mortality worldwide and is predicted to be the 3rd leading cause of death in 2020, due to high smoking rates, air pollution, and an increase in the elderly population ${ }^{1)}$. It is characterized by chronic inflammation and airflow limitation that is usually progressive and irreversible caused by environmental exposure to cigarette smoke, air pollution and various particles or gases ${ }^{2}$. Cigarette smoke contains reactive oxygen species (ROS) and many other chemical components, which triggers the release of chemoattractants, promoting the recruitment of neutrophils and other inflammatory cells ${ }^{3), 4}$. This non-specific immune system mediates the processes of inflammation, fibrosis and proteolysis ${ }^{5}$. In particular, an increase in neutrophils is associated with development of COPD and has been observed in bronchoalveolar lavage fluid (BALF) and sputum

\footnotetext{
- Received : 29 November 2018 - Revised : 14 December 2018

- Accepted : 14 December 2018

$\dagger$ These authors contributed equally to this work

- Correspondence to; Professor Yang-Chun Park, omdpyc@dju.kr

Korean Internal Medicine and Director of the Clinical Trial Center

Dunsan Korean Medicine Hospital of Daejeon University

75, Daedeok-daero 176-beongil, Seo-gu, Daejeon, Republic of Korea 35235

Tel: 82-42-470-9126 (clinic), 82-42-229-6763 (office, Munchang Campus), Fax: 82-42-470-9486
} 
samples obtained from COPD patients. Other inflammatory cells indicate the severity of the disease ${ }^{6}$.

Current conventional treatment for COPD is based on bronchodilators according to present guidelines ${ }^{7}$, although it has limitations in reducing inflammation of the lung and promoting lung functions ${ }^{8)}$. Corticosteroids are also widely used for COPD patients despite its resistance ${ }^{9)}$ and high risk of side effects such as skin bruising, reduction of bone density, etc ${ }^{10)}$. Thus, the need for alternative treatments such as herbal medicines has been increased ${ }^{11)}$ and several herbal medicines including socheongryong-tang ${ }^{12}$, maekmoondong-tang ${ }^{13)}$, chungsangboha-tang $^{14)}, \quad$ sagan-tang $^{15)}$ and gwaruhaengryeon-hwan ${ }^{16)}$ have been studied for COPD patients.

In this study, we developed herbal medicine, GHX02, which contains four herbs originated from gwaruhaengryeon-hwan (GRHRH) in Donguibogam (Principles and Practice of Eastern Medicine) ${ }^{17)}$ and planned to evaluate anti-inflammatory effects of GHX02 on COPD-induced mice. GHX02 was formed by adding Scutellariae Radix to GRHRH. GRHRH already demonstrated its anti-inflammatory effects on COPD and particulate matter induced lung injury on a mouse model ${ }^{16)}$ and previous studies reported that Scutellariae Radix inhibits the production of several inflammatory cytokines ${ }^{18)}$ and has antioxidant effects ${ }^{19}$. We first established COPD mouse model by exposure to the cigarettes smoke extract (CSE) and lipopolysaccharide (LPS). Then, flow cytometric analysis, Enzyme-linked immunosorbent assays
(ELISA) and lung histopathological study was done to assess the immunotherapeutic potential of GHX02.

\section{Materials and Methods}

\section{Preparation of GHXO2}

GHX02 originated from gwaruhaengryeon-hwan (GRHRH) consisits four herbs including Trichosanthis Semen (TS), Armeniacae Semen (AS), Coptidis Rhizoma (CR) and Scutellariae Radix (SR), which were purchased from Human Herbs Co. Ltd. (Kyeongsan, Korea) (Table 1). GHX02 was suspended in distilled water (Choongwae Pharma, Korea) and formulated by boiling 2 times in distilled water at $100{ }^{\circ} \mathrm{C}$ for 2 hours. The volume of distilled water was 10 times of the total herb weight. The mixture was then filtered through a Whatman No. 2 filter (Maidstone, UK), concentrated under vacuum, and freeze-dried. The water extract was evaporated at $45^{\circ} \mathrm{C}$ and subsequently lyophilized. GHX02 showed a yield of the dried ratio of $14.97 \%$ and TS, AS, CR and SR showed 5.34, 14.23, 14.81 and $41.01 \%$ yield of the dried ratio respectively.

\section{Animal experiments}

C57BL/6 mice (6-8 weeks old) were obtained from the Orient Bio Inc. (Seongnam, Korea) and used after 1 week of acclimatization. The mice were housed under pathogen-free conditions with a standard laboratory diet and maintained at a temperature of $22-24{ }^{\circ} \mathrm{C}$, a humidity of $50 \pm 10 \%$ and with controlled day and night cycles ${ }^{20}$. The animal protocol was approved by the committee

Table 1. Components of GHX02

\begin{tabular}{ccccc}
\hline Herb & Latin name & Family name & Lot No. & $\begin{array}{c}\text { Amount } \\
(\mathrm{mg})\end{array}$ \\
\hline Gwaruin & Trichosanthis Semen & Cucurbitaceae & K2714011 & 4,212 \\
Haengin & Armeniacae Semen & Rosaceae & H0114041 & 2,106 \\
Hwangryeon & Coptidis Rhizoma & Ranunculaceae & H0313121 & 2,106 \\
Hwangkeum & Scutellariae Radix & Labiatae/Lamiaceae & H1114031 & 4,212 \\
\hline
\end{tabular}


for animal welfare at Daejeon University (DJUARB2016-009). All experimental procedures were performed in accordance with the Guide for the Care and Use of Laboratory Animals of the National Institute of Health and guidelines of the Institutional Animal Care and Use Committee of the South Korea Research Institute of Bioscience and Biotechnology (Daejeon, Korea).

\section{Preparation of cigarette smoke extract}

CM6 (CORESTA approved Monitor No. 6) reference cigarettes were conditioned under ISO conditions (one puff/min., $35 \mathrm{~mL}$ puff volume over $2 \mathrm{~s}$, every $60 \mathrm{~s}$ ) of temperature $\left(22 \pm 2{ }^{\circ} \mathrm{C}\right)$ and relative humidity (60 $\pm 5 \%$ ) for $48 \mathrm{~h}$ or more. The cigarettes were smoked using an automatic smoking machine (Borgwaldt RM20, Germany) by ISO conditions (puff volume: 35 $\mathrm{mL}$; duration: $60 \mathrm{~s}$; interval: $2 \mathrm{~s})$. Cigarette smoke was trapped on a Cambridge filter pad $(0.22 \mathrm{Om}, \varnothing 4 \mathrm{~mm})$ and extracted with isopropanol as a solvent. Total particulate matter (TPM) was prepared for the whole 2-year period and stored at $-80^{\circ} \mathrm{C}$. TPM was tested immediately after preparation (T0), after 1 month (T1) and 3 months (T3).

\section{Establishment of COPD mouse model and GHXO2 administration}

A COPD mouse model was established by exposure to the CS extract (CSE) and LPS (Sigma-Aldrich, St. Louis, MO, USA) according to previous literature ${ }^{21)}$ (Fig. 1). After intraperitoneal injection of anesthetics, CSE $(1 \quad \mathrm{mg} / \mathrm{mL})$ and LPS $(100 \mu \mathrm{g} / \mathrm{mL})$ were administered by intratracheal injection three times with a 7 day interval. Dexamethasone and all other drugs were orally administrated for 14 days from Day 7 to Day 21. The mice were divided into the following ten groups as follows: ( i ) C57BL/6_Nr (no treatment), (ii) control (CT) group (CSE/LPS), (iii) dexamethasone group (positive control, CSE/LPS + Dexa $3 \mathrm{mg} / \mathrm{kg}$ ), (iv) TS group (CSE/LPS + TS $200 \mathrm{mg} / \mathrm{kg}$ ), ( v ) AS group (CSE/LPS + AS $200 \mathrm{mg} / \mathrm{kg}$ ), (vi) CR group (CSE/LPS + CR $200 \mathrm{mg} / \mathrm{kg}$ ), (vii) SR group (CSE/LPS + SR 200 mg/kg), (viii) GHX02-100 group (CSE/LPS + GHX02 $100 \mathrm{mg} / \mathrm{kg}$ ), (ix) GHX02-200 group (CSE/LPS + GHX02 $200 \mathrm{mg} / \mathrm{kg}$ ), and (X) GHX02-400 group (CSE/LPS + GHX02 $400 \mathrm{mg} / \mathrm{kg}$ ). All mice were observed daily for their general condition, including the behavior, physical appearance, respiratory murmur, hair condition, sensitivity and liveliness.

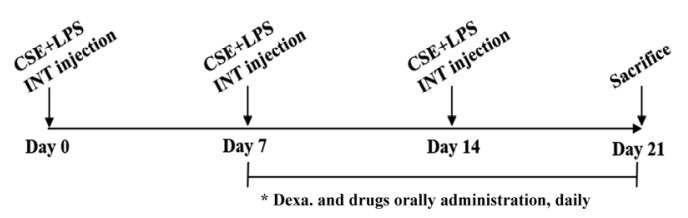

Fig 1. Schematic diagram of chronic obstructive pulmonary disease in mice. Untreated mice received the vehicle, whereas model mice were induced by intratracheal injection of CSE/LPS and then treated with the vehicle (CTL), with Dexa (dexamethasone $3 \mathrm{mg} / \mathrm{kg}$ ), TS (Trichosanthis Semen $200 \mathrm{mg} / \mathrm{kg}$ ), AS (Armeniacae Semen $200 \mathrm{mg} / \mathrm{kg}$ ), CR (Coptidis Rhizoma $200 \mathrm{mg} / \mathrm{kg}$ ), SR (Scutellariae Radix 200 $\mathrm{mg} / \mathrm{kg})$ and GHXO2 (400, 200, $100 \mathrm{mg} / \mathrm{kg})$ for 21 days.

\section{Collection of bronchoalveolar lavage fluid}

On the last day of drug administration, the trachea and airways of the anaesthetized mice were lavaged 3 times using a syringe (containing $1 \mathrm{ml}$ of FBS free DMEM medium) to obtain BALF containing cells from the trachea and lungs. The BALF was centrifuged at $4{ }^{\circ} \mathrm{C}, 2,000 \mathrm{rpm}$ for 5 minutes and the supernatant of BALF was stored at $-25{ }^{\circ} \mathrm{C}$ for the determination of cytokines. The cells isolated from BALF were treated with ammonium chloride (ACK) solution for $3 \mathrm{~min}$ and washed with $1 \%$ FBS free DMEM medium for cell counting using a hemocytometer. 


\section{Flow cytometric analysis}

Antibodies against CD4 (RM4-5, rat IgG2a), CD8 (53-6.7, rat $\mathrm{IgG} 2 \mathrm{a}), \mathrm{CD} 69$ (H1.2F3, rat $\mathrm{IgG})$, and granulocytic marker GR1 (RB6-8C5, rat IgG2b), for flow cytometric analysis, were purchased from Becton Dickinson Pharmingen (San Diego, CA, USA). Cells from the lung and BALF were incubated with fluorescein isothiocyanate- and phycoerythrin- labeled monoclonal antibodies (30 $\mathrm{min})$, washed with phosphate-buffered saline (PBS), fixed with $0.5 \%$ paraformaldehyde (20 min), washed again with PBS, and then stored at $4{ }^{\circ} \mathrm{C}$ until analysis by two-color flow cytometry on a FACS Calibur ${ }^{\mathrm{TM}}$ instrument (BD Biosciences, Mountain View, CA, USA).

\section{Enzyme-linked immunosorbent assays for inflammatory mediators}

The levels of macrophage inflammatory protein 2 (MIP2), tumor necrosis factor- $\alpha$ (TNF- $\alpha$ ), interleukin-17A (IL-17A), and chemokine (C-X-C motif) ligand 1 (CXCL-1) in BALF were determined using enzyme-linked immunosorbent assay (ELISA) kits according to the manufacturer's instructions (R\&D Systems, Minneapolis, MN, USA). The absorbance was measured at $450 \mathrm{~nm}$ using an ELISA reader.

\section{Lung histopathological study}

Mice were perfused with saline, and the whole lung was inflated with fixatives. Lung tissue was fixed in a $10 \%$ formaldehyde solution for $24 \mathrm{~h}$. The tissues were embedded in paraffin, sectioned at $5 \mu \mathrm{m}$ thickness, and stained with hematoxylin-eosin (H\&E) and Masson's trichrome (Sigma-Aldrich Korea). Three separate H\&E-stained sections were evaluated for each mouse under light microscopy at $100 \times$ magnification. To determine the severity of inflammatory cell infiltration, mucus production, peribronchial cells, and goblet cell hyperplasia were quantified in the airway epithelium in a blind manner using the five-point (0-4) grading system as follows: 0 , no cells; 1 , a few cells; 2 , ring of cells two cell layers deep; 3 , ring of cells two-four cell layers deep; 4, ring of cells four cell layers deep ${ }^{22)}$.

\section{Statistical analysis}

Data are expressed as the mean \pm standard error and analyzed using a one-way analysis of variance. Statistical significance was calculated by a nonparametric Mann-Whitney test, followed by Dunnett's multiple comparison test (SPSS version 19.0; IBM, USA). $P<.05$ was considered statistically significant.

\section{Results}

\section{Inhibitory effect of GHXO2 on airway neutrophil accumulation in BALF of COPD mouse model}

To evaluate the effects of GHX02 on the recruitment of cells to the airway, we investigated neutrophils in BALF as neutrophil mediated inflammation plays an important role in the development and pathogenesis of $\mathrm{COPD}^{23)}$. The number of neutrophils was significantly higher in the BALF cytospin of the COPD-induced mice (CSE+LPS) than in that of untreated group (C57BL/6_Nr) (Fig. 2). Then, a significant decrease was observed in the dexamethasone and TS, AS, SR, CR, GHX02 (100, 200, $400 \mathrm{mg} / \mathrm{kg})$ groups, compared with the control group. Herbal formula, GHX02 showed its dose-dependent inhibitory effect better than individual herbs of TS, AS, SR and CR respectively and was not inferior to dexamethasone. 
A

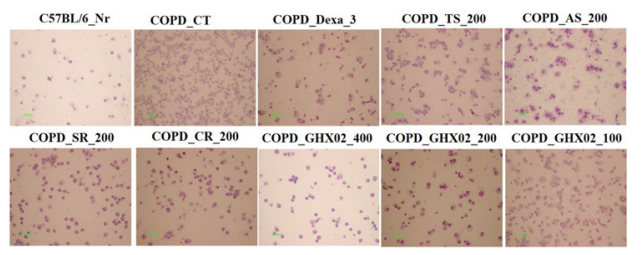

B

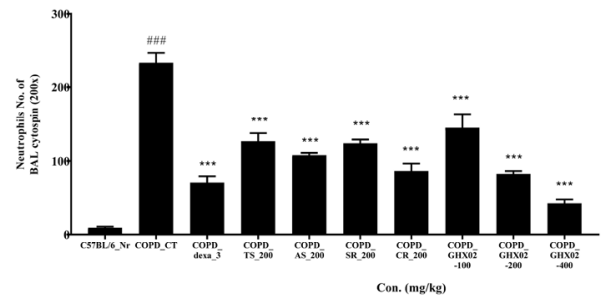

Fig 2. Effect of GHXO2 and individual herbs on (A) cytospin image and (B) neutrophils count of BALF in COPD mice. Mice were challenged by aspiration of CSE+LPS (Control), and then treated with Dexa (dexamethasone $3 \mathrm{mg} / \mathrm{kg}$ ), TS (Trichosanthis Semen $200 \mathrm{mg} / \mathrm{kg}$ ), AS (Armeniacae Semen $200 \mathrm{mg} / \mathrm{kg}$ ), CR (Coptidis Rhizoma $200 \mathrm{mg} / \mathrm{kg}$ ), SR (Scutellariae Radix $200 \mathrm{mg} / \mathrm{kg})$ and GHX02 (400, 200, $100 \mathrm{mg} / \mathrm{kg})$ for 21 days $(n=8)$. All values are mean \pm SEM. *: Significantly different from the Control group $\left(^{*}\right.$ $\mathrm{p}\left\langle 0.05,{ }^{* *} \mathrm{p}\left\langle 0.01,{ }^{* * *} \mathrm{p}\langle 0.001)\right.\right.$.

\section{Inhibitory effects of GHXO2 on absolute numbers of immune cell subtypes in BALF and lungs of a COPD mouse model}

Flow cytometric analysis was used to evaluate the effects of GHX02 on immune cell subtypes ${ }^{24)}$. The numbers of $\mathrm{CD}^{+}, \mathrm{CD} 8^{+}, \mathrm{CD} 69^{+}$, and $\mathrm{CD} 11 \mathrm{~b}^{+} / \mathrm{GR} 1^{+}$ cells in the BALF and lungs of the COPD-induced mice were significantly higher than those in the untreated group and were significantly lower in the GHX02-treated mice than in the control mice (Table 2). Thus, GHX02 showed profound inhibitory effects on airway inflammation in the mouse model of COPD, and these effects were caused by suppression of Th2-type cytokines and neutrophil infiltration.

\section{Inhibitory effects of GHXO2 on inflammatory cytokines in BALF of COPD mouse model}

We measured the levels of COPD-accompanying cytokines in BALF to determine the mechanisms underlying the GHX02-mediated inhibition of airway inflammation. In mice exposed to CSE and LPS, the levels of TNF- $\alpha$, IL-17A, MIP2, and CXCL-1 in BALF were significantly higher than those in the untreated group. However, administration of GHX02 and individual herbs of TS, AS, SR, CR significantly suppressed the increases in TNF- $\alpha$, IL-17A, MIP2, and CXCL-1 in BALF compared with those in the COPD-induced untreated mice (Fig. 3). The inhibitory

Table 2. Quantification of Immune Cell Subtypes in the Lungs and BALF of Mice by FACS Analysis

\begin{tabular}{|c|c|c|c|c|c|c|c|}
\hline \multirow[t]{3}{*}{ Source } & \multirow[t]{3}{*}{ Cell phenotypes } & \multicolumn{6}{|c|}{ Mouse groups } \\
\hline & & \multirow{2}{*}{$\begin{array}{l}\text { Vehicle } \\
\text { control }\end{array}$} & \multicolumn{5}{|c|}{ CSE/LPS-induced COPD mice } \\
\hline & & & $C T L$ & $\begin{array}{c}\text { Dexa } \\
(3 \mathrm{mg} / \mathrm{kg})\end{array}$ & $\begin{array}{c}G H X 02 \\
(100 \mathrm{mg} / \mathrm{kg})\end{array}$ & $\begin{array}{c}G H X 02 \\
(200 \mathrm{mg} / \mathrm{kg})\end{array}$ & $\begin{array}{c}G H X 02 \\
(400 \mathrm{mg} / \mathrm{kg})\end{array}$ \\
\hline \multirow[t]{4}{*}{ Lung } & $\mathrm{CD}^{+} / \mathrm{CD}^{+}\left(1 \times 10^{5}\right.$ cells $)$ & $2.120 \pm 0.031$ & $9.260 \pm 0.088^{\dagger+\dagger}$ & $3.130 \pm 0.063^{* * *}$ & $7.251 \pm 0.091^{* * *}$ & $6.385 \pm 0.065^{* * *}$ & $3.152 \pm 0.042^{* *}$ \\
\hline & $\mathrm{CD}^{+} / \mathrm{CD}^{+}\left(1 \times 10^{5}\right.$ cells $)$ & $0.468 \pm 0.024$ & $2.232 \pm 0.032^{\dagger \dagger}$ & $1.333 \pm 0.029^{* * *}$ & $1.998 \pm 0.083^{* * *}$ & $1.610 \pm 0.053^{* * *}$ & $1.518 \pm 0.043^{* * *}$ \\
\hline & $\mathrm{CD} 9^{+} / \mathrm{CD}^{+}\left(1 \times 10^{5}\right.$ cells $)$ & $0.514 \pm 0.044$ & $4.558 \pm 0.074^{\dagger \dagger \dagger}$ & $1.263 \pm 0.021^{* * *}$ & $3.420 \pm 0.140^{* * *}$ & $2.221 \pm 0.240^{* * *}$ & $1.423 \pm 0.140^{* * *}$ \\
\hline & $\mathrm{GR}^{+} / \mathrm{CD} 11 b^{+}\left(1 \times 10^{5}\right.$ cells $)$ & $1.684 \pm 0.045$ & $5.620 \pm 0.162^{\dagger+\dagger}$ & $2.475 \pm 0.113^{* * *}$ & $4.695 \pm 0.088^{* * *}$ & $4.102 \pm 0.086^{* * *}$ & $3.268 \pm 0.083^{* *}$ \\
\hline \multirow[t]{3}{*}{ BALF } & $\mathrm{CD}^{+} / \mathrm{CD} 3+\left(1 \times 10^{3}\right.$ cells $)$ & $0.484 \pm 0.021$ & $20.993 \pm 0.247^{\dagger+\dagger}$ & $9.165 \pm 0.135^{* * *}$ & $14.783 \pm 0.127^{* * *}$ & $12.152 \pm 0.027^{* * *}$ & $10.854 \pm 0.057^{* * *}$ \\
\hline & $\mathrm{CD}^{+} / \mathrm{CD} 3+\left(1 \times 10^{3}\right.$ cells $)$ & $0.074 \pm 0.0020$ & $3.152 \pm 0.104^{\dagger \dagger \dagger}$ & $2.243 \pm 0.086$ & $2.653 \pm 0.067^{* * *}$ & $2.401 \pm 0.051^{* *}$ & $1.627 \pm 0.063^{* * *}$ \\
\hline & $\mathrm{CD} 9^{+} / \mathrm{CD}^{+}\left(1 \times 10^{3}\right.$ cells $)$ & $0.517 \pm 0.023$ & $24.152 \pm 0.546^{\dagger+\dagger}$ & $10.483 \pm 0.210^{* * *}$ & $19.630 \pm 0.317^{* * *}$ & $15.315 \pm 0.051^{* * *}$ & $11.631 \pm 0.037^{* * *}$ \\
\hline
\end{tabular}

Results are expressed as total absolute numbers (mean $\pm \mathrm{SEM} ; \mathrm{n}=8$ mice per group). $\dagger \dagger+\mathrm{P}<.001$ versus the vehicle group; $* * * \mathrm{P}<.001$ versus the CTL group. BALF, bronchoalveolar lavage fluid; COPD, chronic obstructive pulmonary disease; CSE, cigarette smoke extract; CTL, control; Dexa, dexamethasone; FACS, fluorescence-activated cell sorting; LPS, lipopolysacc 

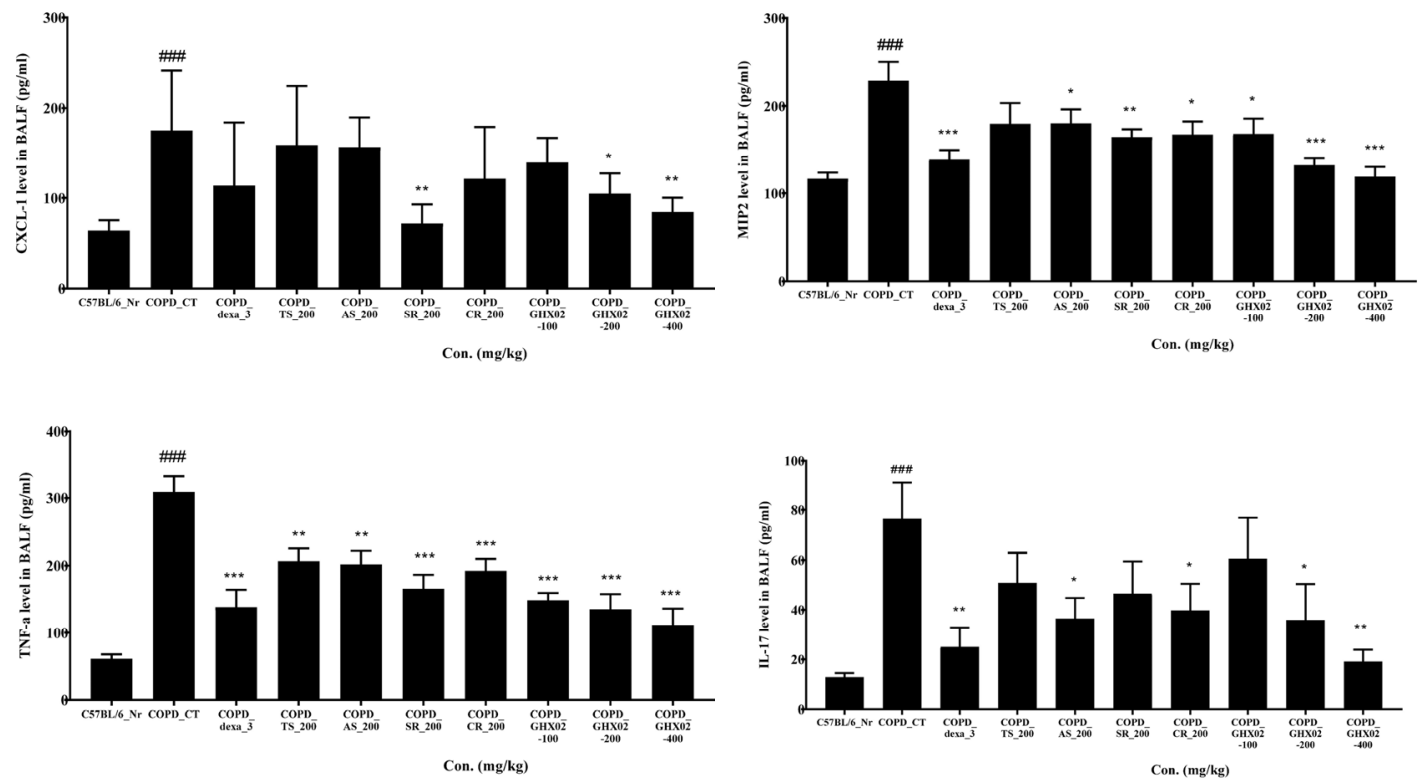

Fig 3. Effect of GHX02 and individual herbs on TNF- $\alpha$, IL-17A, MIP2 and CXCL-1 production of BALF in COPD mice. Mice were challenged by aspiration of LPS+CSE (Control), and then treated with Dexa (dexamethasone $3 \mathrm{mg} / \mathrm{kg}$ ), TS (Trichosanthis Semen 200 mg/kg), AS (Armeniacae Semen 200 mg/kg), CR (Coptidis Rhizoma 200 mg/kg), SR (Scutellariae Radix $200 \mathrm{mg} / \mathrm{kg}$ ) and GHX02 (400, 200, $100 \mathrm{mg} / \mathrm{kg})$ for 21 days $(\mathrm{n}=8)$. *: Significantly different from the Control group (* $\mathrm{p}\left\langle 0.05,{ }^{* *} \mathrm{p}\left\langle 0.01,{ }^{* * *} \mathrm{p}\langle 0.001)\right.\right.$.
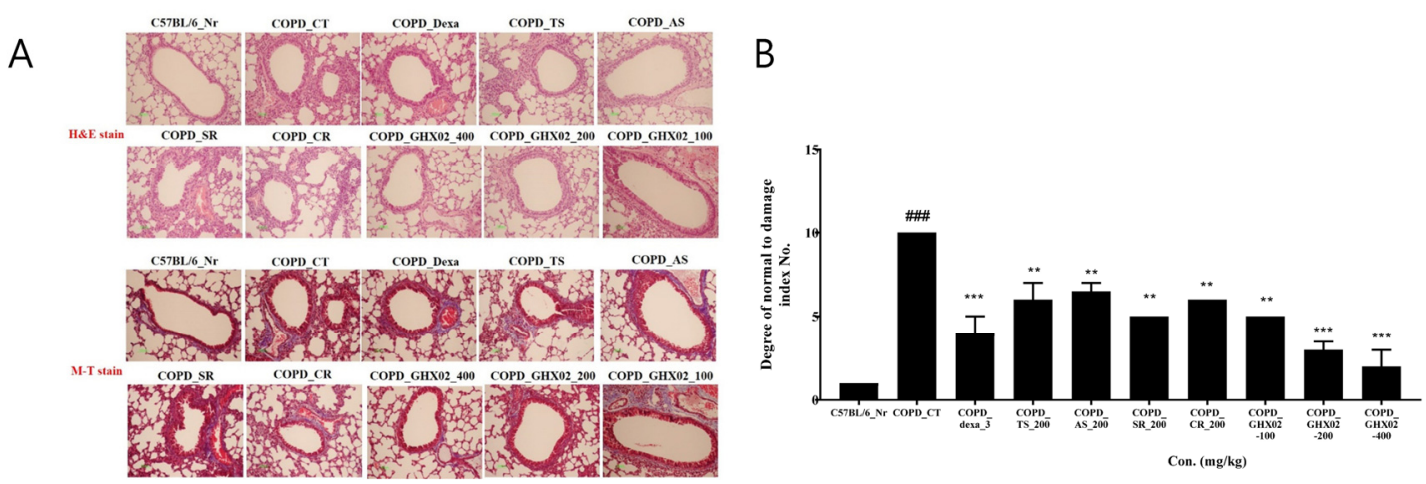

Fig 4. Effects of $\mathrm{GHXO2}$ and individual herbs on (A) histopathological changes and (B) histology scores in the lung of a CSE/LPS-induced murine model of chronic obstructive pulmonary disease. Untreated mice received the vehicle, whereas model mice were induced by intratracheal injection of CSE/LPS and then treated with the vehicle (CTL), Dexa (dexamethasone $3 \mathrm{mg} / \mathrm{kg}$ ), TS (Trichosanthis Semen $200 \mathrm{mg} / \mathrm{kg}$ ), AS (Armeniacae Semen $200 \mathrm{mg} / \mathrm{kg}$ ), CR (Coptidis Rhizoma $200 \mathrm{mg} / \mathrm{kg}$ ), SR (Scutellariae Radix $200 \mathrm{mg} / \mathrm{kg}$ ) and GHX02 (400, 200,100 $\mathrm{mg} / \mathrm{kg}$ ) for 21 days. Lungs were fixed, sectioned, and stained with hematoxylin and eosin (H\&E) and Masson's trichrome (M-T) stains. (A) Representative sections from each treatment group are shown. (B) Quantitative analysis of the degree of lung tissue damage in the sections. Data are from individual mice, with the arithmetic means shown in the histogram. All values are mean \pm SEM. *: Significantly different from the Control group (* $\left.\mathrm{p}<0.05,{ }^{* *} \mathrm{p}<0.01,{ }^{* * *} \mathrm{p}<0.001\right)$. 
effect of GHX02 was shown to be greater than that of individual herbs, TS, AS, SR, and CR.

\section{Effects of GHXO2 on lung inflammation in COPD mouse model}

The lungs of the COPD mice showed histopathological features typical for inflammatory lung tissues, such as distinct infiltration of leukocytes, goblet cell hyperplasia, and erosion in perivascular and peribronchial areas. In contrast, histological sections from the dexamethasone, TS, AS, SR, CR and GHX02-treated mice revealed significantly reduced airway inflammation in lung tissues (Fig. 4A). GHX02 treatment markedly attenuated the damage when compared to that of the COPD-induced mice. The index score, representing the degree of histopathological changes, increased in COPD-induced mice compared with that of the untreated mice. However, the GHX02-treated mice showed significantly decreased index score compared with that in COPD-induced mice. This result indicates that the COPD model was successfully established and GHX02 obviously improved the pathological injury of COPD (Fig. 4B).

\section{Discussion}

In the circumstances that the worldwide prevalence of COPD has substantially increased and no direct treatment has yet been developed ${ }^{25)}$, various herbal medicines are being used in the Oriental countries. In this study, we demonstrated anti-inflammatory and lung injury inhibitory effects of herbal medicine GHX02 on COPD mouse model and suggest GHX02 as a promising therapeutic agent for COPD.

COPD is associated with chronic inflammation of the lungs and airways, caused by environmental exposure to cigarette smoke (CS) and air pollution ${ }^{26)}$. CS provokes severe inflammation mediated by NF- $\kappa$
B-dependent production of cytokines, inducing the transcription of various inflammatory mediators including IL-1 $\beta, \quad$ IL-6 and TNF- $\alpha$. Those pro-inflammatory cytokines and chemokines recruit neutrophils to the lung tissue causing lung injury ${ }^{27)}$. Exposure to CSE and LPS induced COPD-like pathological changes such as inflammatory cell accumulation in the lung parenchyma, hyperplasia of goblet cells, enlargement of airway space, and increase of elastin and collagen. This model encompasses major risk factors of COPD, including both smoking and acute exacerbation $^{21)}$. In this model, inhibitory effect of GHX02 on inflammation was evaluated.

GHX02 and all of individual herbs of TS, AS, CR and SR significantly reduce the number of neutrophils in BALF and the number of $\mathrm{CD}^{+}, \mathrm{CD}^{+}, \mathrm{CD} 69^{+}$, and $\mathrm{CD}_{1} \mathrm{~b}^{+} / \mathrm{GR} 1^{+}$cells in BALF and lung cells in all dosage of GHX02 (100, 200, $400 \mathrm{mg} / \mathrm{kg})$. This result demonstrates that GHX02 and individual herbs suppress Th2-type cytokines and neutrophil infiltration, although herbal formula of GHX02 showed better effects than individual herbs.

GHX02 also suppresses the increase of the pro-inflammatory cytokines, TNF- $\alpha$ and IL-17. TS, AS, CR and SR also showed inhibitory effects on TNF$\alpha$ and AS, CR showed effects on IL-17. Cigarette smoke can activate macrophages to produce TNF- $\alpha$ and is measured in large quantities in COPD, especially during exacerbations. TNF- $\alpha$ induces the gene expression of many pro-inflammatory cytokines via $\mathrm{NF}-\mathrm{kB}$ transcription factor activation ${ }^{28)}$. Interleukin (IL)-17A correlates with the presence of neutrophils and the severity of loss of lung function. IL-17A plays a critical role for the innate immune response through its ability to indirectly mobilize neutrophils, promoting airway neutrophils through the induction of granulocyte chemokines and growth factors $^{29)}$. Therefore, GHX02 is considered to have an inhibitory effect on neutrophil-related 
inflammation by decreasing pro-inflammatory cytokines. In addition, GHX02 effectively inhibits airway inflammation by regulating the expression of inflammatory cytokines through the blockade of MIP2 and CXCL-1 secretion. GHX02 and SR significantly suppressed the increases in CXCL-1 and MIP2 was decreased in treatment with GHX02 and AS, SR, CR. CXCL-1 is known to increase in the sputum of patients with COPD, and CXCL-1 and MIP2, which mainly secreted from macrophages, are reported to accumulate neutrophil and other inflammatory cells into lesions ${ }^{30)}$. Overall, GHX02 exhibited anti-inflammatory effects by inhibiting migration of inflammatory cells and expression of pro-inflammatory cytokines in a COPD mouse model. This anti-inflammatory effect could also be demonstrated by the result that GHX02 markedly attenuated the damage of lung.

This study provides evidence that the treatment of GHX02 and individual herbs exert preventive and therapeutic effects against COPD mouse model. Among individual herbs, CR significantly showed inhibitory effect on airway neutrophil accumulation and SR decreased the level of CXCL-1 effectively. Our results are consistent with previous reports indicating anti-inflammatory effects of GRHRH ${ }^{16)}$ and as well as $\mathrm{TS}^{31)}, \mathrm{AS}^{32)}, \mathrm{CR}^{33), 34}, \mathrm{SR}^{18)}$. These data demonstrated that GHX02 may be a promising strategy for treatment of COPD. Further studies to discover the therapeutic mechanisms of GHX02 and clinical trials for COPD patients will be conducted.

\section{Acknowledgment}

This research was supported by the Korea Health Technology R\&D Project, Ministry of Health \& Welfare, Republic of Korea (grant number: HI15C0006) and Korea Institute of Oriental Medicine (grant number: K17510).

\section{References}

1. Woodruff PG, Agusti A, Roche N, Singh D, Martinez FJ. Current concepts in targeting chronic obstructive pulmonary disease pharmacotherapy: making progress towards personalised management. The Lancet. 2015;385(9979):1789-98.

2. Spurzem JR, Rennard SI. Pathogenesis of COPD. in Seminars in respiratory and critical care medicine 2005. New York:Thieme Medical Publishers. c1994-.

3. Barnes PJ. Inflammatory mechanisms in patients with chronic obstructive pulmonary disease. Journal of Allergy and Clinical Immunology. 2016;138(1):16-27.

4. Cosio MG, Saetta M, Agusti A. Immunologic aspects of chronic obstructive pulmonary disease. New England Journal of Medicine. 2009;360(23):2445-54.

5. Oostwoud L, Gunasinghe P, Seow H, Ye J, Selemidis S, Bozinovski S, et al. Apocynin and ebselen reduce influenza A virus-induced lung inflammation in cigarette smoke-exposed mice. Scientific reports. 2016;6:20983.

6. Caramori G, Casolari P, Giuffrè S, Barczyk A, Adcock I, Papi A. COPD pathology in the small airways. Panminerva medica. 2011;53(1):51-70.

7. Celli BR, MacNee W, Agusti A, Anzueto A, Berg B, Buist AS, et al. Standards for the diagnosis and treatment of patients with COPD: a summary of the ATS/ERS position paper. European Respiratory Journal. 2004;23(6):932-46.

8. Donohue JF, Fogarty C, Lötvall J, Mahler DA, Worth H, Yorgancioglu A, et al. Once-daily bronchodilators for chronic obstructive pulmonary disease: indacaterol versus tiotropium. American journal of respiratory and critical care medicine. 2010;182(2):155-62.

9. Barnes PJ, Adcock IM. Glucocorticoid resistance in inflammatory diseases. The Lancet. 
2009;373(9678):1905-17.

10. Calverley PM, Anderson JA, Celli B, Ferguson GT, Jenkins C, Jones PW, et al. Salmeterol and fluticasone propionate and survival in chronic obstructive pulmonary disease. New England Journal of Medicine. 2007;356(8):775-89.

11. George J, Ioannides-Demos LL, Santamaria NM, Kong DC, Stewart K. Use of complementary and alternative medicines by patients with chronic obstructive pulmonary disease. Medical Journal of Australia. 2004;181(5):248.

12. Lee ES, Han JM, Kim MH, Namgung U, Yeo Y, Park YC. Effects of Inhalable Microparticles of on Chronic Obstructive Pulmonary Disease in a Mouse Model. Journal of Korean Medicine. 2013;34(3):54-68.

13. Kim HW, Yang SY, Kim MH, NamGung U, Park YC. Protective effects of Maekmundong-tang on elastase-induced lung injury. The Journal of Korean Medicine. 2011;32.

14. Lee H, Kim Y, Kim HJ, Park S, Jang YP, Jung S, et al. Herbal formula, PM014, attenuates lung inflammation in a murine model of chronic obstructive pulmonary disease. Evidence-Based Complementary and Alternative Medicine. 2012;2012.

15. Han JM, Yang WK, Kim SH, Park YC. Effects of Sagan-tang and individual herbs on COPD mice model. Herbal Formula Science. 2015;23(2):171-87.

16. Lee CW, Yang WK, Lyu YR, Kim SH, Park YC. Effects of Gwaruhaengryeon-hwan on COPD and Particulate Matter Induced Lung Injury on a Mouse Model. The Journal of Internal Korean Medicine. 2017;38(3):353-66.

17. Heo J. Dong-Ui-Bo-Gam. Hadong:Donguibogam Publish. 2005:1341.

18. Kim OS, Seo CS, Kim Y, Shin HK, Ha H. Extracts of Scutellariae Radix inhibit low-density lipoprotein oxidation and the lipopolysaccharide-induced macrophage inflammatory response. Molecular medicine reports. 2015;12(1):1335-41.

19. Guo M, Zhang N, Li D, Liang D, Liu Z, Li F, et al. Baicalin plays an anti-inflammatory role through reducing nuclear factor- $\mathrm{\kappa B}$ and $\mathrm{p} 38$ phosphorylation in S. aureus-induced mastitis. International immunopharmacology. 2013;16(2):125-30.

20. Gueders MM, Paulissen G, Crahay C, Quesada-Calvo F, Hacha J, Van Hove C, et al. Mouse models of asthma: a comparison between $\mathrm{C} 57 \mathrm{BL} / 6$ and $\mathrm{BALB} / \mathrm{c}$ strains regarding bronchial responsiveness, inflammation, and cytokine production. Inflammation research. 2009;58(12):845.

21. Mizutani N, Fuchikami JI, Takahashi M, Nabe T, Yoshino S, Kohno S. Pulmonary emphysema induced by cigarette smoke solution and lipopolysaccharide in guinea pigs. Biological and Pharmaceutical Bulletin. 2009;32(9):1559-64.

22. Tanaka H, Masuda T, Tokuoka S, Komai M, Nagao $\mathrm{K}$, Takahashi Y, et al. The effect of allergen-induced airway inflammation on airway remodeling in a murine model of allergic asthma. Inflammation Research. 2001;50(12):616-24.

23. O'donnell R, Breen D, Wilson S, Djukanovic R. Inflammatory cells in the airways in COPD. Thorax. 2006;61(5):448-54.

24. Kim V, Han MK, Vance GB, Make BJ, Newell JD, Hokanson JE, et al. The chronic bronchitic phenotype of COPD: an analysis of the COPDGene Study. Chest. 2011;140(3):626-33.

25. Adeloye D, Chua S, Lee C, Basquill C, Papana A, Theodoratou E, et al. Global and regional estimates of COPD prevalence: Systematic review and meta-analysis. Journal of global health. 2015;5(2).

26. Gan WQ, FitzGerald JM, Carlsten C, Sadatsafavi 
M, Brauer M. Associations of ambient air pollution with chronic obstructive pulmonary disease hospitalization and mortality. American journal of respiratory and critical care medicine. 2013;187(7):721-7.

27. Meijer M, Rijkers GT, Van Overveld FJ. Neutrophils and emerging targets for treatment in chronic obstructive pulmonary disease. Expert review of clinical immunology. 2013;9(11):1055-68.

28. Barnes PJ. The cytokine network in asthma and chronic obstructive pulmonary disease. The Journal of clinical investigation. 2008;118(11):3546-56.

29. Prause O, Bossios A, Silverpil E, Ivanov S, Bozinovski S, Vlahos R, et al. IL-17-producing $\mathrm{T}$ lymphocytes in lung tissue and in the bronchoalveolar space after exposure to endotoxin from Escherichia coli in vivo-effects of anti-inflammatory pharmacotherapy. Pulmonary pharmacology \& therapeutics. 2009;22(3):199-207.

30. Caramori G, Adcock IM, Di Stefano A, Chung KF. Cytokine inhibition in the treatment of COPD. International journal of chronic obstructive pulmonary disease. 2014;9:397.

31. Van Minh C, Nhiem NX, Yen HT, Van Kiem P, Tai BH, Anh HLT, et al. Chemical constituents of Trichosanthes kirilowii and their cytotoxic activities. Archives of pharmacal research. 2015;38(8):1443-8.

32. Chang HK, Yang HY, Lee TH, Shin MC, Lee MH, Shin MS, et al. Armeniacae semen extract suppresses lipopolysaccharide-induced expressions of cycloosygenase- 2 and inducible nitric oxide synthase in mouse BV2 microglial cells. Biological and Pharmaceutical Bulletin. 2005;28(3):449-54.

33. Yokozawa T, Ishida A, Cho EJ, Kim HY, Kashiwada Y, Ikeshiro Y. Coptidis Rhizoma: protective effects against peroxynitrite-induced oxidative damage and elucidation of its active components. Journal of pharmacy and pharmacology. 2004;56(4):547-56.

34. Kim JM, Jung HA, Choi JS, Lee NG. Identification of anti-inflammatory target genes of Rhizoma coptidis extract in lipopolysaccharide-stimulated RAW264. 7 murine macrophage-like cells. Journal of Ethnopharmacology. 2010;130(2):354-62.

\section{ORCID}

Won-Kyung Yang: https://orcid.org/0000-0002-4493-9787 Yee Ran Lyu: https://orcid.org/0000-0002-9823-0618 Seung-Hyung Kim: https://orcid.org/0000-0002-4598-1733 Yang Chun Park: https://orcid.org/0000-0002-5645-869X 